\title{
Empire and Children's Literature: Changing Patterns of Cross-Cultural Perspective
}

\author{
Don Randall
}

Published online: 24 October 2009

(C) Springer Science+Business Media, LLC 2009

\begin{abstract}
Robert Louis Stevenson's poem "Foreign Children," Rudyard Kipling's poem "We and They," and Frances Temple's youth novel The Beduins' Gazelle are the texts submitted to detailed analysis in this article, which examines cross-cultural perspectives in relation to imperial and post-imperial social contexts. Stevenson is shown to portray the basic structure of an imperial cross-cultural perspective, which Kipling problematizes and calls into question. Analysis of Temple reveals her awareness of the problems and limitations that inhere in an imperial perspective and shows that her work presents innovative, contemporary approaches to the representation of cross-cultural perspectives.
\end{abstract}

Keywords Robert Louis Stevenson - Rudyard Kipling · Frances Temple · Imperialism and culture - Postcolonial theory and critique $\cdot$ History of childhood . Acculturation - Cultural difference $\cdot$ Travel and migration

The "Golden Age" of children's literature, extending from the last decades of the nineteenth century to the early decades of the twentieth century, produced an enormous proportion of the British and American children's texts commonly considered "classic" today. Interestingly, historian Eric Hobsbawm (1987),

Don Randall is Associate Professor in the Department of English Language and Literature at Bilkent University (Ankara, Turkey), where he began teaching in 1999. He received his Ph.D. from the University of Alberta in 1995, and subsequently was awarded two postdoctoral fellowships, at The University of Calgary (1996-1997) and at Queen's University at Kingston (1997-1999). His main research areas are postcolonial literature and British imperial literature. He has published numerous articles and is the author of two books: Kipling's Imperial Boy: Adolescence and Cultural Hybridity (Palgrave, 2000) and David Malouf (Manchester University Press, 2007).

D. Randall ( $($ )

Department of English Language and Literature, Faculty of Humanities and Letters,

Bilkent University, 06800 Bilkent, Ankara, Turkey

e-mail: randall@bilkent.edu.tr 
speaking of the same epoch, characterizes it very differently, calling it "the Age of Empire." This article begins by affirming that this double-naming of a single "Age" is not random but highly significant, that modern imperialism inscribed itself both broadly and deeply upon cultural processes and productions, and that writing for children is by no means exempt from, or innocent of, this inscription. By examining the close connection between culture and imperialism (most famously argued by Edward Said, 1993), my critical process will strive to elucidate the impact of imperial social context upon literature, and to show also some aspects of what postcolonial scholarship can bring to the study of children's literature: what kinds of critical intervention, perspectives, and practices it can make available or enable. My organizing concern will be with cross-cultural perspectives, with the ways in which literature for children portrays cultural difference. My sense is that an imperial inflection in writing for children is most consistently in evidence, and most troubling, with respect to the perspectives upon cultural others that it offers, and the understanding and response that its readers learn to bring to such encounters with others. Similarly, I believe that re-examining and restructuring cross-cultural perspectives is an important challenge facing contemporary child- and youthdirected writing.

I will begin by briefly establishing the special importance, in modern Western societies, of children and their social formation. I shall then consider short works by two distinguished "Golden Age" authors, Robert Louis Stevenson and Rudyard Kipling, to exemplify children's literature's engagement with the modern imperial social context, to show how empire shapes the representation of the child and how it brings questions of cross-cultural perspective into prominence. Taking from Kipling the crucial theme of travel, the argument then moves on to consider contemporary writing for children. The main text at this point is American, Frances Temple's novel The Beduins' Gazelle (1996), but the argument still proceeds by examining and evaluating the representation of cultural difference from a cross-cultural perspective.

As the work of scholars such as Philippe Ariès (1962) and Norbert Elias (1982) has made clear, the modern child is a focal point for questions of socialization, "civilization," and political formation. Ariès speaks of the child's "specialization" to delineate the particular clothes, playthings and pastimes which came to be associated with certain European children. Specialization produces various kinds of encoded child-for example, the schoolboy-by ascribing distinctive traits and meanings to children. Certain coded versions of the child can then circulate, in literature and other public discourses, as figures, as recognizable, conventionalized signifying elements. Such figures can be put to work in texts as instruments that make social distinctions that render visible and meaningful the way that social subjects become distributed and arranged hierarchically. In short, Ariès's work suggests a technology of childhood, a set of material practicesspecial clothing, special schooling - that shape the experience of childhood and its representation.

As Norbert Elias argues in The Civilizing Process, Europe in the medieval and early modern period engaged in an increasingly complex process of civilization, which established over time an organizing principle for social relations. For the 
scholar of modern children's literature, Elias makes two major points, which he puts forward independently, but which need to be considered interdependently. The first point is that questions of civility centre upon the child as civilization's subject-inprocess. Attaining a high degree of civilization is seen to increase prestige and power, so the child becomes a focus of class-linked hopes and fears. The second point is that European civilization, which begins as a process, is later understood as an achievement: it founds the self-conception of the new national cultures and guides their conception and evaluation of non-European cultures. As the imperial nations of modern Europe established dominion over non-European peoples, these same nations (most notably, Great Britain and France) continuously engaged in the scrutiny and domestication of children. Civilization, modern Europe's selfspecifying achievement, continued-and even today continues-to be considered as a process for children and cultural others.

Not surprisingly then, modern literature for children does much to shape and specify the child's being, doing, and becoming. In many of the texts of children's literature, child characters - and through them, child readers-are called upon to learn and adopt certain sociocultural ideals and aspirations. Quite frequently a child character is presented as a representative embodiment of social ideals and aspirations. Literature for children effectively undertakes to make a child, a making that inscribes the particularity of contemporary social relations. Thus, childhood is not to be understood as given, as a natural and transparent order of experience. If one strives to make a child, then one must concede that a process of becoming precedes whatever character or state of being one may wish, ultimately, to ascribe to the child. This making occurs in time, and it will change with the times. However, one must recognize that the conception and development of a literature for children is not universal or transcultural, nor certainly transhistorical; it is an idea, an invention, very closely linked with modern Western societies. Taking my examples from British and Anglo-American social contexts, I shall show how intimate is the connection between the literary representation of children and concurrent imperial projects and concerns.

Robert Louis Stevenson's "Foreign Children," published in A Child's Garden of Verses (1885), provides a compelling example:

Little Indian, Sioux or Crow,

Little Frosty Eskimo,

Little Turk or Japanee,

$\mathrm{O}$ ! don't you wish that you were me?

You have seen the scarlet trees

And the lions over seas;

You have eaten ostrich eggs,

And turned the turtles off their legs.

Such a life is very fine,

But it's not so nice as mine;

You must often, as you trod,

Have wearied not to be abroad. 
You have curious things to eat,

I am fed on proper meat;

You must dwell beyond the foam,

But I am safe and live at home.

Little Indian, Sioux or Crow,

Little Frosty Eskimo,

Little Turk or Japanee,

O! don't you wish that you were me? (Stevenson, 1925, pp. 19-20)

The dynamics of this poem are clear enough. The verse is organised around structures of self and other. It is, moreover, a self-consolidating discourse for the child speaker, one that does its work most compellingly by ascribing to others a desire for the privileged place of the self: "O! don't you wish that you were me?" Just as clearly, the poem manifests a close concern with questions of cultural context: a British child is sharply distinguished from a group of non-European children, and this differentiation of children turns upon the topic of civility.

To grasp more thoroughly the cultural work Stevenson's verse performs, one needs to examine it from a postcolonial perspective. Indeed, the poem can be understood as a small-scale enactment of the pattern of modern intercultural relations Gayatri Spivak (1988) describes in "Can the Subaltern Speak?" Spivak argues that "Europe" or "the West" represents itself as the foundational "Subject" of the modern world, the source and impetus of global developments. In relation to this "Subject of Europe," cultural differences are not plural and multilateral, for it is only in relation to Europe that significant, or meaningful differences arise. All nonEuropean societies and their constituencies thus become "the Other of Europe" (Spivak, 1988, p. 281). In other words, "Europe" gives shape and definition to the non-European world, but submits to no reciprocal shaping and defining. The "Subject of Europe" simply constitutes itself and its other; more crucially, this Subject constitutes itself by constituting its other, knowing itself only in relation to a "Not-Europe" of its own creation.

Spivak's concern is with macrostructure, but her thinking, if cogent, should elucidate microstructure, the little instances manifesting the logic of the much larger whole; as, for instance, in a politician's speech, an article in a newspaper, or a poem for children. With respect to Stevenson's poem, Spivak's theory directs our attention to the production of foreign childhood for the British child-speaker. Rather than enacting encounter, the poem stages difference. And one should note at the same time that the poem does not stage a plurality of differences: although the childspeaker invokes Sioux, Turk, "Japanee," and others, the foreign children collectively represent " $a$ life," an exotic life promiscuously composed of scarlet trees, ostrich eggs, and the like. The evocations of the foreign children's experiences have, of course, no ethnographic value. The verse simply offers signs of other experience, signs of cultural otherness. The writing aims, certainly, to portray a child's developing awareness of self and world, and thus it should not surprise us that the speaker works with available materials, with little fragments of imagined experience that the home-bound British child might attach to imagined children. The speaker participates childishly in the knowledge-system, or "episteme," Spivak describes. 
His own experience of self and world coheres and is validated by establishing an imaginary relation with foreign children, with children of Britain's imperial periphery. The full import of this self-consolidating action becomes clearer as the poem moves to its resolution, through "proper meat" to the evocation of "home" as the proper place. Proper food and, by extension, proper experience are not only suitable, right and decent, but also, crucially, one's own, as in the notion of le propre in French. The proper, especially when one thinks of property, is defined in relation to self, and it is also self-defining. By opposing proper meat to the curious things the foreign children eat, the poem shows links with discourses of civility and hygiene. But more importantly, it recalls Elias's sense that, for Europe in the imperial age, civilization is a special cultural achievement and a measure of European cultural superiority. When the child, at the conclusion of the verse, asks again, "don't you wish that you were me?" the question clearly has become rhetorical. Of course, all the other children would wish to be the self-possessed child-speaker. The childspeaker's experience is proper: it is suitable, fitting, exclusively one's own, and it is the only proper experience for which the verse provides a place.

In offering this short reading of Stevenson's poem, I do not mean to suggest that the literary archive of Britain's high imperial age will invariably be read as exemplifying Spivak's thesis. Crucial to her conception of the Western episteme is a recognition that it delimits knowledge production, determining what cannot be known as well as what can be. The knowledge-system works, in part, by exclusion, and through exclusion it falsifies. It does not acknowledge the differences that "Europe" or "the West" contains within itself, nor the diversity of non-European cultures. Moreover, it leaves unacknowledged the transformative impact nonEuropean cultures might have upon the "Subject of Europe." Returning then to Stevenson's poem, we might expect that it would strain against Eurocentric, imperial paradigms even as it enacts them; that it would resist the meaningdelimiting power of the episteme even as it conforms to it. In this respect, one should take note of the poem's final, ineluctable return to the other's desire and to a desire for the other's desire. The final "O! don't you wish that you were me?" should remind us that the British child's priority depends on the foreign child's recognition of and desire for the speaker's particular prestige and privilege. The relation between self and other is inscribed, in the last analysis, not as a stark opposition but as more of a radical contingency.

To communicate more plainly this notion of an ambivalence in enunciation, the sense that enunciation might strain against the episteme even as it conforms to it, I turn now to another poem. Rudyard Kipling's "We and They" was published in 1919, a little more than three decades after Stevenson's "Foreign Children," and at the end of the cataclysmic First World War fought between the imperial powers in Europe. When Kipling wrote "We and They" both children's literature's "Golden Age" and "the Age of Empire" were coming to an end:

Father, Mother, and Me,

Sister and Auntie say

All the people like us are We,

And every one else is They. 
And They live over the sea,

While We live over the way,

But-would you believe it?-They look upon We

As only a sort of They!

We eat pork and beef

With cow-horn-handled knives.

They who gobble Their rice off a leaf,

Are horrified out of their lives;

While They who live up a tree,

And feast on grubs and clay,

(Isn't it scandalous?) look upon We

As a simply disgusting They!

We shoot birds with a gun

They stick lions with spears.

Their full dress is un-,

We dress up to Our ears.

They like Their friends for tea.

We like Our friends to stay;

And, after all that, They look upon We

As an utterly ignorant They!

We eat kitcheny food.

We have doors that latch.

They drink milk or blood,

Under an open thatch.

We have Doctors to fee.

They have Wizards to pay.

And (impudent heathen!) They look upon We

As a quite impossible They!

All good people agree,

And all good people say,

All nice people like Us, are We

And every one else is They:

But if you cross over the sea,

Instead of over the way,

You may end by (think of it!) looking on We

As only a sort of They! (Kipling, 1990, pp. 631-632)

Whereas Stevenson's child speaks confidently and consistently in the first-person singular, Kipling's child-speaker immediately acknowledges that individual identity takes shape only in relation to a group. Stevenson's child is securely "at home"; for Kipling's, the sense of identity and home is an effect of perspective. Indeed, by the end of the poem, Kipling's child arrives at the shocking recognition- "Think of it!"- that awareness of others' perspectives might provoke estrangement, and the loss of a clear sense of group-oriented identity. In the poem's three middle stanzas, 
the speaker contrasts the cultural practices of "We" and "They," and ends each stanza with an unfavourable judgment of "We" by "They": "We" is denounced as "simply disgusting," "utterly ignorant," and finally "quite impossible." In this also, Kipling's poem differs sharply from Stevenson's, in which the child is figured as a site of desire, a focal point of others' approval and envy. Kipling's child-speaker's primary group evidently maintains itself in the face of others' disapproval by a shared set of understandings and assumptions, a discourse composed of things on which "All good people agree," things that "all good people say." This discourse accounts for the speaker's naïve, formulaic (and intentionally amusing) pronouncements upon cultural others. Kipling's poem has no more ethnographic value than Stevenson's-although both poems communicate an appreciable amount about commonplace British attitudes to non-European cultures. Kipling's poem, however, repeatedly acknowledges that others have their own perspectives, and that these perspectives are unsettling for the "We." Awareness of other perspectives ultimately gives rise to the ominous possibility of an alienating perspective that breaks down primary group identification and the conception of the familiar and self-same that sustains it.

Travel, from one cultural location to another, is the crucial factor that breaks down the self-defining binary opposition between the perspective of that which is "We" and that which is "They." In other words, "If you cross over the sea/Instead of over the way," moving not simply within the sphere of your cultural home but beyond its bounds, you may lose your assured grasp of "We"; you may take up, at least to a degree, the unsettling perspectives available to "They." Kipling was a traveller, an imperial traveller, one who spent sizable portions of his childhood and adolescence in India, one who acquired in adulthood a quite extensive experience as a resident of South Africa, and also of the United States. It is not so surprising, therefore, that this author should intuit, in the early decades of the twentieth century, the impact of global cultural developments that have asserted themselves so compellingly as principal topics for late-twentieth-century thinking on questions of culture. I am speaking of migrancy_ "the state or condition of being a migrant" $(O E D)$ —and exile, and their articulation in postcolonial scholarship. As Said (2000) puts the case, migrancy and exile have become ordering concepts for reflections upon the experience of culture and cultural identity. Increasingly, one's sense of one's culture must be processed in relation to discontinuities of experience and in the awareness that "homes ... are always provisional." However, Said's thinking does not entrench itself in loss and longing: it affirms instead the migrant's capacity to productively interrogate cultural formations, to pose enriching questions and to inhabit cultures differently. In Said's words, "Exiles cross borders, break barriers of thought and experience" (p. 170). Following a line of thinking closely related to Said's, James Clifford (1992) challenges the very notion of culture as organic and somehow rooted in time and place. We must, in Clifford's view, rethink culture in relation to migrancy, recognizing that cultures travel, as do individuals, and that cultures travel both with individuals and in more mediated ways - as is evident if one considers the peregrinations and exchanges marking popular music today. Clifford's conception of "travelling cultures" recodes what culture is, and how we experience it, focusing attention on questions of plural histories, displacements, diversified moments of interaction and confrontation, defamiliarization and experimentation. Traditional 
"localizing strategies" (ibid., p. 97)—and geographic distributions of cultures—are very much called into question if one comes to think of "culture as travel" (ibid., p. 103). The envisioning of what culture is must then submit to relocation and dislocation. To bring this back to Spivak, we see that, in our time, cultural conditions strain the production of "the West" as a culturally specific, monological knowledgesystem. As Iain Chambers (1994) puts the case, “"out there' ... begins to appear 'in here', ... the encounter between diverse cultures, histories, religions and languages ... emerges at the centre of our daily lives" (p. 2).

To bring these considerations back to children's literature, and most particularly to contemporary children's literature, one must recall first that today's world is not the same as that of Stevenson. This is not to say that culture did not travel then, in 1885. "Proper meat" for Stevenson's child would almost certainly include tea, and tea, by 1885 , had become, through imperial travel and appropriation, an everyday element in the practice of British propriety. But there are nonetheless important matters of degree: travelling cultures, culture as travel-these are more obviously pertinent in the late twentieth and early twenty-first century. In measuring that difference of degree, one should note that Stevenson's poem aptly addresses its cultural circumstances and historical moment. In its small way, the poem demonstrates and confirms Britain's very real status as a successful imperial power; it articulates an envisioning of the cultural implications of Britain's imperial status. If, however, one figures different children for different times, how then does contemporary children's literature register the effects of travelling cultures and the multiple negotiations of cultural difference such travelling will entail?

Answering this last question could take a scholar to various sites of study. In recent decades, much engaging writing for children has come out of California. Gary Soto's Baseball in April (2000) is a collection of stories that engages with conventional, established sites of American male youth culture-bike riding, the cute girl at school, and (of course) baseball. But the stories, in various ways, renegotiate these familiar sites of American cultural identity in relation to chicano experience. One encounters, for example, a born-in-America chicano boy who eats his first-ever Danish (itself a well-travelled element of American food culture), and assimilates the experience of eating this new pastry by comparing it to the familiar empanada. But California, as represented by Soto and others, is only one site for examining the impact of travel and exchange on children's literature. Salman Rushdie's Haroun and the Sea of Stories (1990) also merits attention: this postcolonial and postmodern text both employs and subverts conventions of Western children's literature, revealing that children's literature itself provides an instance of culture that travels. But the text that I wish to consider in greater detail registers cultural migration in yet another way. Frances Temple's "junior" novel The Beduins' Gazelle performs imaginatively a cultural crossover, a passage into realms of culture where the writer has limited claims to familiarity. For the purposes of this article, what interests me most about narratives of cultural crossover is that they recapitulate, in their originating gesture, the textual practice of celebrated imperial authors. One may take the example of Kipling, who, in his 1901 novel Kim, presumed to represent the cultures of colonial India from a dual perspective, from the perspective of power, of imperial mastery, and also from the perspective of easy, 
intimate, free-wheeling participation. Given such powerful and enduringly alluring imperial precedents, it may be difficult, in our time, to evaluate a text that crosses borders of cultural identity, especially if it is intended for juvenile readers. Can such a text be considered a productive response to new cultural conditions arising from the migration of peoples and of cultures? Can it suggest new ways of perceiving, interpreting, and understanding differences?

Temple's writing evidences an awareness of Euro-imperial vision and perspective, but appeals for and puts into practice a renegotiation of that vision and perspective. Her novel articulates, quite frankly and straightforwardly, a contemporary ethics for crossover writing. This is not to say that this one book will turn my article into a clear narrative of progress, affirming that we, in our time, have moved definitively beyond the various biases of less enlightened times. But the novel does demonstrate that some contemporary writing for children is responsive to the changed conditions of current cultural lives. Its particular sense of imaginative possibility should also be briefly noted. The Beduins' Gazelle, Temple's last, and posthumously published book, offers a warm and sympathetic envisioning of ArabMuslim cultural worlds, and thus proposes a cross-cultural adventure that may be especially challenging for American writers and readers, after September 11, 2001.

Temple sets her story in North Africa, in the region that is now Morocco. Her prefatory note specifies the year as "680 of the Hegira ..., the year of our Lord 1302" (1996, p. viii). An ethics of cross-cultural representation is already evident here: one is given two culturally specific designations of a single temporal moment. As the novel's social world unfolds, it is shown to have two main locations, the desert and the city. The desert is represented by two Bedouin tribes, the Beni Khalid (or Khalidi) and the Beni Shummar (or Shummari). The portrayal of the city centres upon the University at Fez, a place of power-social, intellectual, religious, and political power. It is in this notably non-European power-centre, however, that the novel first situates European participation and perspective: Étienne, a young scholar-priest from France, is among the major characters associated with the University. Thus, in a fundamental way, Temple conforms to a representational practice characterizing imperial cross-cultural adventure tales, which typically show a young European forging a passage into strange, exotic realms. But whereas Kim, Kipling's venturesome boy-spy, roams about India under the nickname "Little Friend of All the World" (Kipling, 1987, p. 3), Étienne is much less acclimatized and bears, significantly, a much less distinguished designation: Étienne-Roum. "Roum," deriving from the Arabic word for Rome, is appended to Étienne by means of a not very comfortable synecdoche: he is generalized as a European foreigner, a stranger-from-Europe. Although we occasionally see and experience the novel's imaginative world in relation to Étienne, he is only one of several focalised characters, one of several interactive islands of experience that Temple portrays. Étienne's experience manifests $a$ way of seeing and knowing, not the way.

Étienne approaches the cross-cultural adventure as a learner rather than a knower. This learner's disposition is clearly evident, for example, when Étienne questions young Atiyah, a prince of the Beni Khalid, hoping to understand the reasons for the antagonism that marks relations between the novel's two Bedouin tribes. "So," asks Étienne-Roum, "are the Shummari much like the Khalidi?" In response, 
Atiyah just stared at him, then looked away. "Like, and not like," he said thoughtfully. "Now that I have seen the ways of city people, I see that to them, we and the Beni Shummar would seem as like as these two olives." He opened his hand and popped the last two wizened olives into his mouth.

After much chewing, he added, "But to ourselves we are not." (Temple, 1996, p. 110)

This passage challenges the regime of knowing that tends to elide differences among cultural groups other than one's own. At the same time, the passage inscribes the awareness of that regime of knowing among those who are submitted to it. Atiyah has come to recognize that city dwellers see only Bedouin, not distinct tribes. This sense of city-perspective, of city-knowledge, reminds us that the world has many centres, and that the Bedouin are marginal in relation to Fez, the local centre of power. Fez-dwellers imagine a margin of strangeness around a familiar, empowered, central world. This centrist thinking distorts, generalizing the differences that stand at a distance; it does not really know what it knows. But, of course, Atiyah is also now in the city-indeed, in the University. His arrival there offers a challenge to his sense of himself, but also presents him with the opportunity to learn about himself and to show others his own new-discovered specificity. He can take the question of cultural identity into his mouth, as it were, and give it a good, thorough chew. And, through processes of encounter and initiation, he can offer a new perspective to Étienne, whose response to Atiyah's few brief statements is instructive. Étienne says simply, "Tell me" (ibid., p. 110)— that is, tell me more, take me further.

Not too many pages later, Étienne is taken further. Étienne-Roum finds himself in a Shummari camp. He encounters a Shummari woman, Saffiya: "She was robed in black from head to toe, so mysterious to him that he had to remind himself that, just like him, she had a complicated everyday life of her own" (ibid., p. 126). This short passage clearly signals the impulse to exoticize cultural others; Étienne must catch himself, "remind himself" that the stranger is not mystery incarnate, although a mystery to him. Étienne also recognizes that to see Saffiya as the embodiment of mystery would be to simplify her and to condemn her to an exile of incommunicable difference. Countering his initial impulse, Étienne constitutes her as another subject (and an other-subject), a distinct but equally valid version of human possibility. Tellingly, Saffiya's life is envisioned as "complicated" rather than, say, complex. The writing does not idealize the life experience of either of the two characters, nor does it adopt an idealized view of what it means, generally, to be acculturated.

Temple's use of Étienne, although generally very much to be admired, does reveal a notable limitation: Étienne is never the estranged object of another's gaze. As noted before, he represents only one of the novel's orienting perspectives, but if he is present in a narrative situation, scenes and events unfold in relation to his perspective. Admittedly, in an uncomfortable moment Étienne realizes that Atiyah, upon their first meeting, is not sure that the young Frenchman is human. But Étienne always masters such encounters with the troubling perspectives of strangers. In the present case, he perceives, without being told, that Atiyah is not certain he is human, and this perception is part of his perspective upon Atiyah. For the most part Temple's narrative works rigorously to present a fictive world of decentred cross- 
cultural encounters and exchanges. Therefore, the European stranger, Étienne, should on occasion show himself to readers as the odd, uncomprehended stranger, as the one who appears in a distorted, incomplete form in the eyes of those he encounters. To fulfil more thoroughly its commitment to decentred and decentring cross-cultural negotiations, the novel should, at times, show Étienne from an other's defamiliarizing perspective, show him in the position of the misapprehended object (a status suggested by his naming as Étienne-Roum), and not only in his relatively comfortable position as a subject who sees and learns among other subjects who see and learn in their different ways.

These last remarks notwithstanding, Temple's writing clearly shows that she is productively responsive to new cultural conditions arising in relation to travelling cultures. Her novel presents multifaceted testings of cultural identity, showing how the acculturated self is made and transformed. Transformation is the most crucial consideration here, because the novel writes about transformation as a matter of negotiating various differences - again, the plural must be stressed. Temple's characters (especially Étienne, but not only him) learn to see and understand others differently, and thus to understand themselves differently. The Beduins' Gazelle effectively demonstrates that travelling cultures today make cultural participation more a matter of differences and their interactions, much less a matter of difference and its opposition to an empowered norm or standard. The work carefully refuses, and to a degree disarticulates, Eurocentrism. It includes a character of European origin and acculturation, but shows that Étienne, like the other young people he encounters, is very much in process, engaged in self- and other-discovery. Precisely because his is not an empowered perspective, Étienne looks upon his new-found worlds with eyes that seek to learn from others, that seek new possibilities for the experience of community with others.

Temple's novel provides some grounds for optimism with respect to the possible paths of development children's literature may pursue in the twenty-first century. For Temple's young characters, cross-cultural encounters are challenging and enriching; such encounters offer perspectives upon other cultures that are to be understood as important learning opportunities. Temple dispenses with the empowered perspective characterizing imperial representation, which Stevenson's poem stages so clearly and which Kipling's poem begins to call into question. In Temple's view, no particular formation of culture enjoys any special authority and prestige. Her business is to multiply perspectives, and to use each of them to question and transform the others. Her writing thus effectively meets the challenge to re-examine and restructure cross-cultural perspectives, which I began by specifying as the main challenge facing contemporary writing for children.

\section{References}

Ariès, Philippe. (1962). Centuries of Childhood: A Social History of Family Life. New York: Knopf. Chambers, Iain. (1994). Migrancy, Culture, Identity. New York: Routledge.

Clifford, James. (1992). Traveling Cultures. In Lawrence Grossberg, Cary Nelson and Paula Treichler (Eds.), Cultural Studies (pp. 96-116). London: Routledge. 
Elias, Norbert. (1982). The Civilizing Process: State Formation and Civilization. Oxford: Basil Blackwell.

Hobsbawm, E. J. (1987). The Age of Empire, 1875-1914. London: Weidenfeld and Nicolson.

Kipling, Rudyard. (1987). Kim. Ed. Alan Sandison. Oxford: Oxford University Press.

Kipling, Rudyard. (1990). The Complete Verse. London: Kyle Cathie.

Rushdie, Salman. (1990). Haroun and the Sea of Stories. London: Granta/Penguin.

Said, Edward W. (1993). Culture and Imperialism. New York: Knopf.

Said, Edward W. (2000). Reflections on Exile and Other Essays. Cambridge, MA: Harvard University Press.

Soto, Gary. (2000). Baseball in April and Other Stories. Boston, New York: Houghton Mifflin Harcourt. Spivak, Gayatri Chakravorty. (1988). Can the Subaltern Speak? In Cary Nelson and Lawrence Grossberg (Eds.), Marxism and the Interpretation of Culture (pp. 271-313). Urbana: University of Illinois Press.

Stevenson, Robert Louis. (1925). Poems. London: J. M. Dent \& Sons.

Temple, Frances. (1996). The Beduins' Gazelle. New York: HarperCollins. 